\title{
Incorporation of aquatic ecology to the hydrological investigation of ecosystems in the high Andes
}

\author{
Henrietta Hampel*, Jenny Cocha, Diego Vimos \\ Grupo de Ciencias de la Tierra y del Ambiente, Dirección de Investigación, Universidad Cuenca, Av. \\ 12 de Abril s/n, Cuenca, Ecuador \\ *E-mail: hennihampel@gmail.com \\ Fecha de recepción: 28 de septiembre 2010 - Fecha de aceptación: 6 de noviembre 2010
}

\section{RESUMEN}

Los servicios derivados de los ecosistemas de alta montaña contribuyen al bienestar de millones de personas quienes por tanto dependen del buen funcionamiento de estos ecosistemas. La investigación hidrológica tiene mayores antecedentes en el Sur del Ecuador (Austro) pero las investigaciones ecológicas sobre la estructura y funcionamiento de los diferentes ecosistemas de alta montaña son poco comunes. La combinación de investigación hidrológica y ecológica proveería un diagnóstico más integrado sobre el funcionamiento e importancia de estos ecosistemas, lo cual podría luego ser la base de nuevos proyectos y medidas de protección y conservación. Este artículo describe la investigación en curso que tiene como objetivo general el efectuar la caracterización detallada de la estructura de los ecosistemas acuáticos basada en campañas de muestreos en los diferentes niveles tróficos y el estudio de la limnología. Los objetivos más específicos se ocupan de (1) la definición del estado de conservación de los ecosistemas de alta montaña; (2) el estudio del efecto de la cubierta vegetal sobre la estructura de las comunidades acuáticas; (3) la determinación del impacto de la conectividad hidrológica sobre la composición de la fauna de diferentes ecosistemas; y (4) la investigación del efecto de la radiación ultra violeta sobre las comunidades acuáticas. Las actividades de la investigación en curso tratarán: la planificación detallada de las campañas de muestreo, el desarrollo de campañas intensivas de muestreo, trabajo de laboratorio y el análisis de datos empleando diferentes métodos estadísticos. Los resultados de la investigación mejorarán el conocimiento sobre el funcionamiento de los ecosistemas de alta montaña.

Palabras clave: Ecosistemas acuáticas, montañas altas, cubierta de vegetación, radiación ultravioleta, conectividad hidrológica, funcionamiento de ecosistema.

\begin{abstract}
Ecosystem services in high mountains support the life of millions of people dependent on the well functioning of these ecosystems. Collection and interpretation of hydrologic data in South Ecuador has a long record but almost no ecological investigation has been carried out in the various aquatic ecosystems. Combined, hydrologic and ecological research would provide an integrated picture on the functioning and importance of high mountain ecosystems which in future could be the base of new projects and policies on protection and conservation measures at local and regional scale. This article describes an ongoing research with general objective the characterization of the structure of various aquatic ecosystems based on the sampling of different trophic levels and analysis of the limnology. More specific objectives are: (1) definition of the conservation status of high mountain lagoons; (2) analyzing the effect of vegetation cover on aquatic community structure; (3) assessing the impact of hydrological connectivity on the faunal composition of different ecosystems; and (4) examining the effect of ultraviolet radiation on the status of aquatic communities. Project activities cover: detailed planning of sampling activities, implementation of sampling campaigns for the collection of needed samples and information, laboratory work, data analyses using various statistical methods and publishing results in extension and scientific manuscripts. The project will improve the knowledge of the ecosystem functioning of high mountain ecosystems in South Ecuador.
\end{abstract}


Keywords: Aquatic ecosystems, high mountain, vegetation cover, ultraviolet radiation, hydrological connectivity, ecosystem functioning.

\section{INTRODUCTION}

Ecosystems generate a range of essential goods and services for human well-being, collectively called ecosystem services (Nelson et al., 2990). The Millennium Ecosystem Assessment distinguishes four categories of ecosystem services: provisioning (e.g., seafood, water), regulating (e.g., climate, floods), supporting (other services, e.g., pollination and pest control for food production), and cultural (e.g., serenity, inspiration).

High mountains are producing half of the worldwide freshwater resources and millions of people in South America are dependent on these for hydropower, irrigation, domestic and industrial uses. As pressure on these environments increases due to global changes and anthropogenic impacts, it is clear that balancing the needs of water for humans against ecosystems (terrestrial and aquatic) is, and will increasingly become, a premier issue (Petts et al., 2006). If water resources in the high mountains are not properly managed they will rapidly decline resulting in the loss of biodiversity and the distortion of the water regulating capacity of the wet ecosystems of the Andes (Celleri and Feyen, 2009). Furthermore, one of the fundamental factors for sustainable development is water availability, not only because of human needs, but also because water and temperature are primary factors in shaping plant biomass distribution through biological evolution, and succession (Zalewski, 2002). By positive feedback mechanisms with the atmosphere, vegetation cover stabilizes the global heat budget and regulates the amount of water and nutrients retained and released by ecosystems to ground and surface waters (Baird and Wilby, 1999). According to Zalewski $(2000,2002)$ provides the control and regulation of water and nutrient cycling, by synergistically integrated hydrological and biotic processes at the catchment scale, opportunities for the enhancement of the absorbing capacity of ecosystems against human impacts. Field and experimental studies showed that regulating the hydrology of systems, the biological dynamics of these systems (e.g., negative symptoms of eutrophication) are affected and can be controlled (Mitsch, 1993).

Due to the complexity of ecosystems it is increasingly agreed that scientific research trying to understand the functioning of these systems and how these systems control the environment require the effective integration of disciplines (Kundzewicz, 2002). In most of the developing countries, such like Ecuador, monitoring stations have been established to collect quantitative hydrological data with the objective to provide information on the temporal and spatial variability of water availability. This activity being the input for hydrological research has not been complemented by data collection in support of research in other disciplines, such as geophysics, biology, and socio-economy. Biological/ecological research could help to understand the structure and functioning of high mountain ecosystems and forms the basis to any conservation and protection measures.

Ecological research has demonstrated that food webs in nature contain hundreds to thousands of species, reticulately connected via multiple species links of various strengths in the same and different habitats (Polis and Strong, 1996). Therefore to understand the functioning of an ecosystem it is necessary to consider different trophic levels (i.e., microorganisms, plankton, macroinvertebrates, fish, etc.). In Ecuador most research focuses on macroinvertebrates and investigates the environmental factors which influence their distribution (Jacobsen et al., 1997; Jacobsen and Encalada, 1998; Sites et al., 2003). Some papers report on the sampling of zooplankton communities in high mountain lagoons (e.g., Barros and Carrasco, 2006) but most of these manuscripts are highly descriptive not providing insight in the functioning of these systems. Freshwater algae, involving the identification of algal communities and their temporal evolution, is an important tool for assessing the quality of aquatic ecosystems and to predict the direction of future changes (Calado et al., 2005). For instance in Europe, phytoplankton was chosen as key biological quality element for the establishment of the Water Framework Directive ecological status in reservoirs and lakes. In Ecuador, research on freshwater phytoplankton and their role in the different ecosystems does not exist primarily by lack of appropriate monitoring programs. It also explains why ecosystem assessment in Ecuador is partial. 
High mountain catchments in the Andes encompass several different aquatic ecosystems (i.e., rivers, marshes, lagoons and ponds), which are connected on the landscape level. In the páramo, environmental conditions (i.e., rainfall, soil water content, evapotranspiration, etc.) are relatively constant (Celleri and Feyen, 2009) creating a stable environment. As such any change in these conditions, depending on the buffering capacity of the ecosystem, could strongly deregulate the stability of the aquatic communities. In addition, the relative high and fairly uniformly distributed rainfall and low evapotranspiration guarantee hydrological connectivity between the different water bodies and it is suspected that any change in environmental condition might have a cascading effect on aquatic ecosystems. To fully understand and conserve the integrity of aquatic ecosystems at catchment level it is essential to study the diversity, connectivity and vulnerability of all aquatic species. The biological functioning of these systems should be fully understood before further studies could evaluate the impact of natural or anthropogenic induced changes.

This article discusses the research activities deployed with the general objective to define the baseline relation between the natural factors vegetation cover, hydrological connectivity and ultraviolet radiation and the structure and functioning of high mountain aquatic ecosystems at different trophic levels.

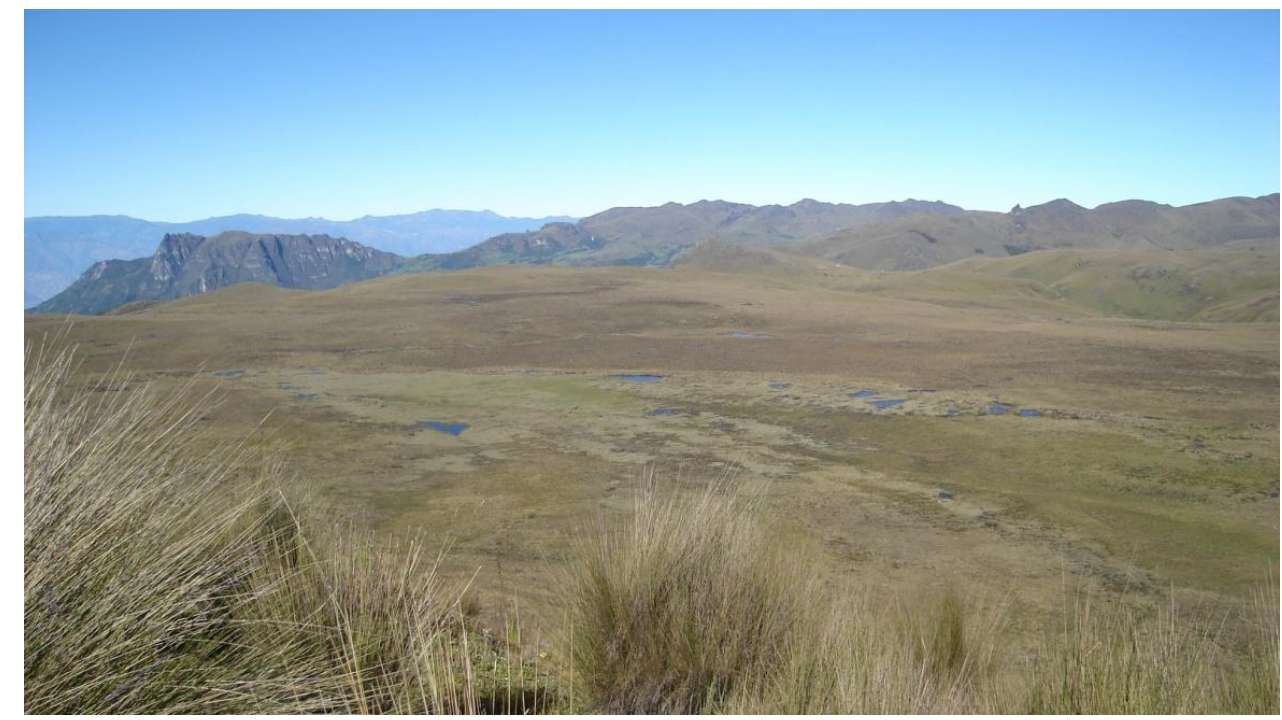

Figure 1. Picture illustrating sampled small ponds in the Zhurucay catchment.

\section{MATERIALS AND METHODS}

Aquatic sampling campaigns are initiated in the following areas:

(1) The small lagoons in the microcatchment of the river Zhurucay $\left(13,92 \mathrm{Km}^{2}\right)$ are situated in the south west of Ecuador in the area called Quimsacocha (Fig. 1). The altitude ranges from 3400 to $3900 \mathrm{~m}$ above sea level, with a mean terrain slope of $25.53 \%$. The sampling campaign of various small lagoons with similar size, all situated in a circle of $300 \mathrm{~m}$ enables quantifying the effect of hydrological connectivity in periods of high and low rainfall. Two rivers (Fig. 2) in the Zhurucay microcatchment having similar characteristics (substrate, size, runoff, etc.) but different vegetation cover (i.e., pajonal and Polylepis forest) are also sampled for analyzing the effect of vegetation cover on the aquatic communities.

(2) The microcatchment of Mazar lies in the catchment of the Paute River. The catchment occupies $165,77 \mathrm{Km}^{2}$ with different vegetation cover (pasture, agriculture, high mountain rainforest, pajonal). A river with similar characteristics (substrate, size, runoff, etc.) like the rivers in the 
Zhurucay microcatchment was chosen for sampling. This river is situated in a basin mainly covered with rainforest.

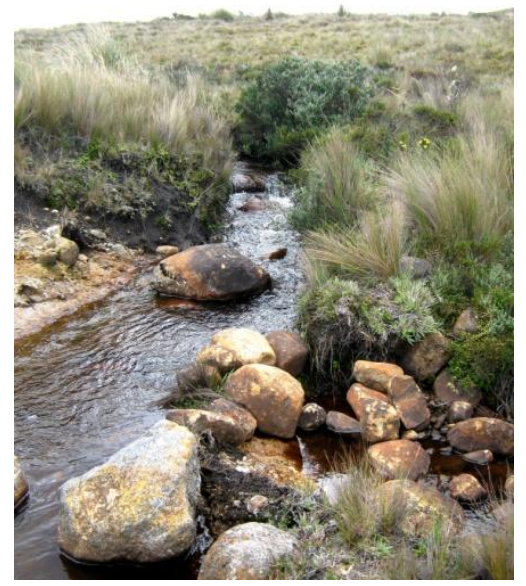

(a)

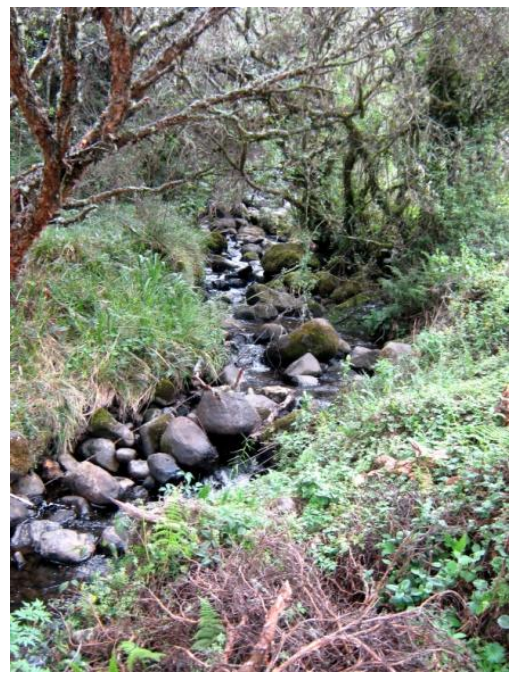

(b)

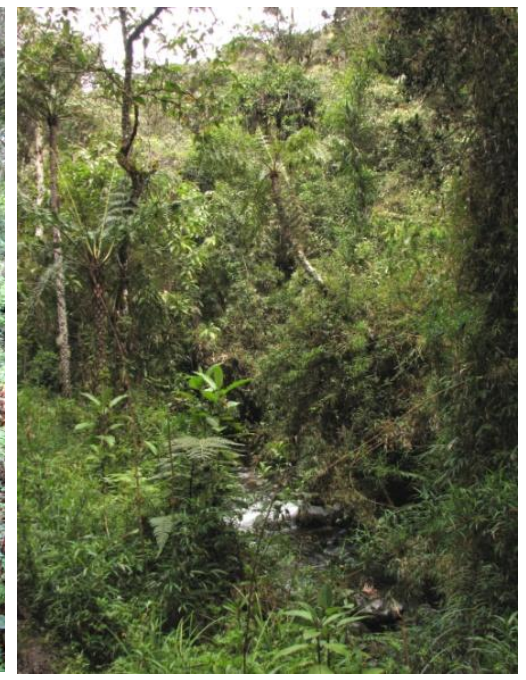

(c)

Figure 2. General view of the 3 sampled river systems, respectively with pajonal (a), Polylepis forest (b) and high mountain rainforest (c) cover.

(3) The lagoon of Torreadora, in Cajas National Park (Fig. 3), was chosen to explore the effect of ultraviolet (UV) radiation on the aquatic communities. The lagoon is situated $2^{\circ} 46^{\prime} 25^{\prime \prime} \mathrm{S}$ and $79^{\circ} 13^{\prime} 20^{\prime \prime} \mathrm{W}$, at an altitude of $3900 \mathrm{~m}$ above sea level, occupying an area of 19.2 ha and has a maximum depth of $40 \mathrm{~m}$.

Macroinvertebrates are sampled along a $50 \mathrm{~m}$ transect using a Hess cylinder (Fig. 4a), taking 5 replicates with a monthly frequency, providing a quantitative measure of the number of macroinvertebrates per square meter (ind $\mathrm{m}^{-2}$ ). For qualitative sampling of macroinvertebrates, for example in small lagoons, a 250 micron mesh hand net (Fig. 4c) is used.

Together with the sampling of macroinvertebrate, water samples are collected and analyzed for chlorophyll a, total phosphorus, nitrate, hardness and alkalinity. At the moment of sampling also the water temperature, dissolved oxygen, turbidity, conductivity and $\mathrm{pH}$ are measured. Zooplankton and phytoplankton are sampled using plankton net with different mesh size, 64 and 10 micron respectively (Fig. 4b), filtering a defined volume of water to obtain a quantitative measure expressed in number of individuals per liter. For studying the effect of ultraviolet radiation on the zooplankton and phytoplankton population stratified water samples to a depth of $40 \mathrm{~m}$ are collected in the Torreadora lagoon using the Van Dorn sampler (Fig. 4d). The sampler collects a defined volume of water. Water samples are filtered using the plankton net to obtain for each depth a representative sample of the zooplankton and phytoplankton population. Additionally, samples are taken at each depth from which 50 zooplankton adults are selected to analyze the carotenoid concentration. Zooplankton produces carotenoid to cope with UV radiation. UV damages zooplankton and other organisms mainly by photo-produced changes in the cell. As defence mechanism zooplankton relies on the production of photo-protective pigments, more in particular carotenoid molecules. As a consequence of this mechanism the concentration of carotenoid in zooplankton is a direct measure of the accumulated UV radiation. In situ the temperature, dissolved oxygen, turbidity, conductivity and $\mathrm{pH}$ are measured; and in the laboratory the concentration of chlorophyll a, dissolved organic carbon, nitrate and total phosphorous are defined. Additionally, the attenuation of UV-A and UV-B along the depth of the lagoon Torreadora is measured with a radiometer. Macroinvertebrates and zooplankton are preserved in a $4 \%$ formaldehyde solution. A mixture of lugol and formaldehyde at a final concentration of $4 \%$ is used to preserve the phytoplankton samples. 


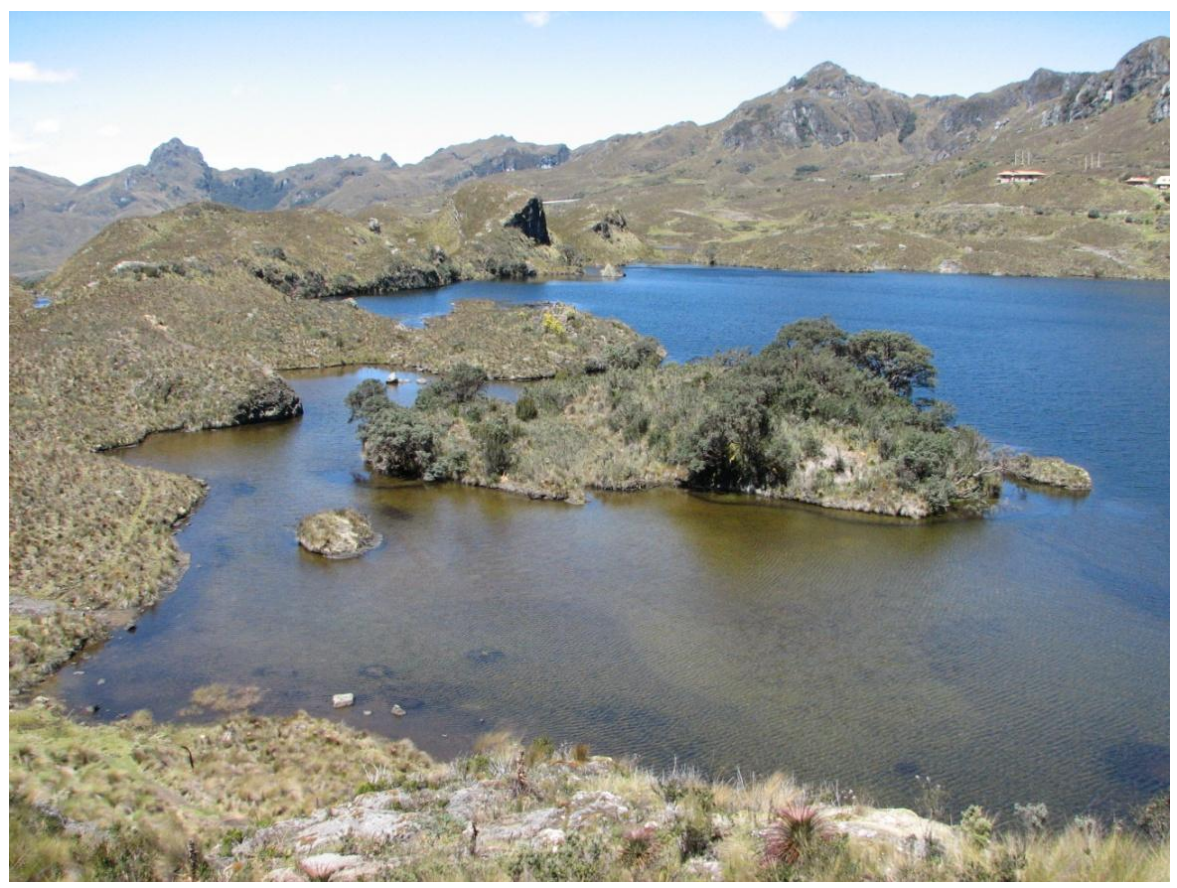

Figure 3. Lagoon of Torreadora in Cajas National Park.
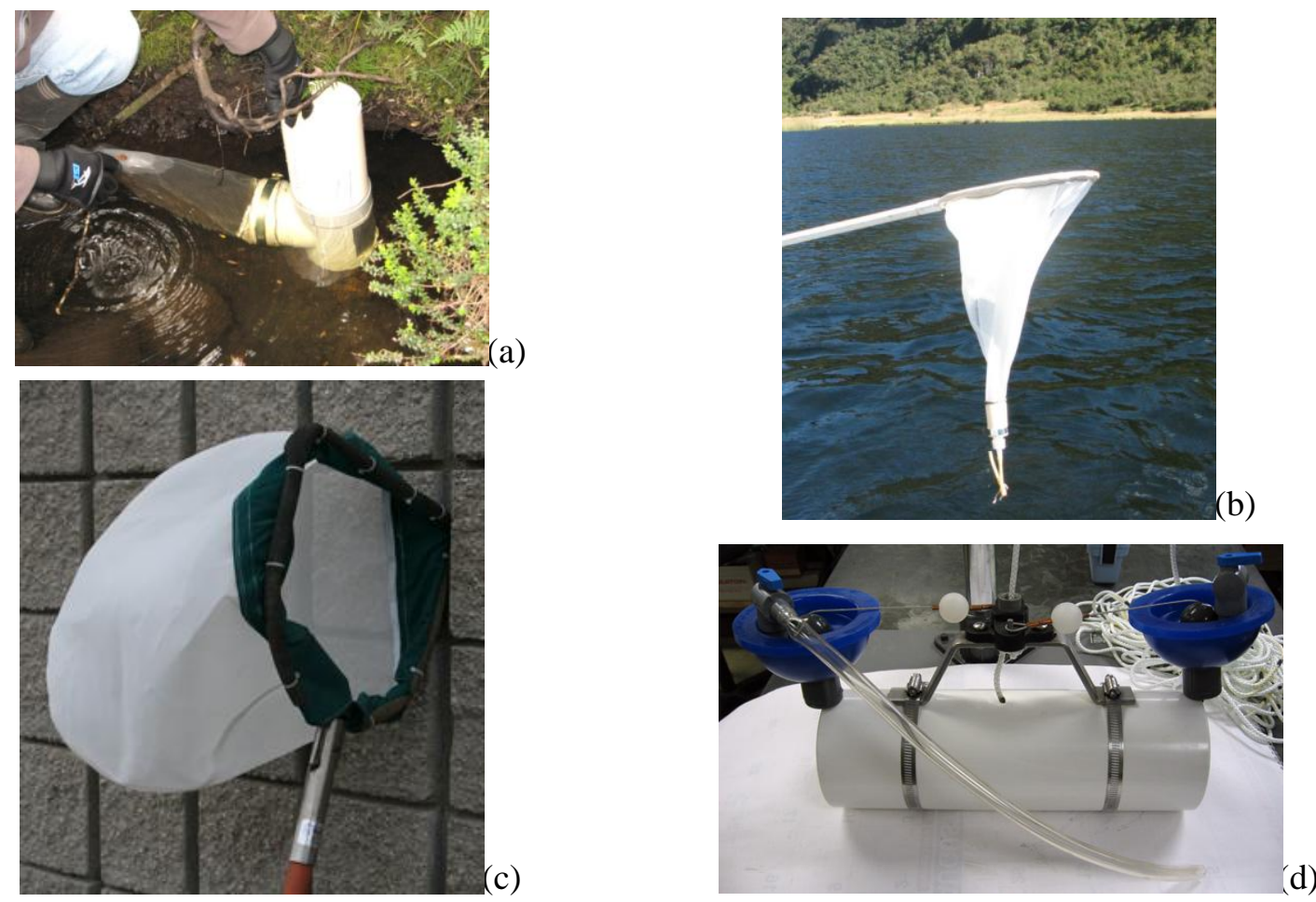

Figure 4. Sampling devices used for fieldwork: a) Hess cylinder; b) plankton net; c) hand net; d) Van Dorn sampler.

In the laboratory samples (Fig. 5) are identified to the lowest taxonomic level using different identification keys (i.e., de Bicudo and Menezes 2006; Dominguez and Fernandez, 2009; Smirnov 
1996). The chemical composition of water samples are analyzed using standard methods (Andrew et al., 2005). Carotenoid in the zooplankton samples is extracted and analyzed by spectrophotometry.
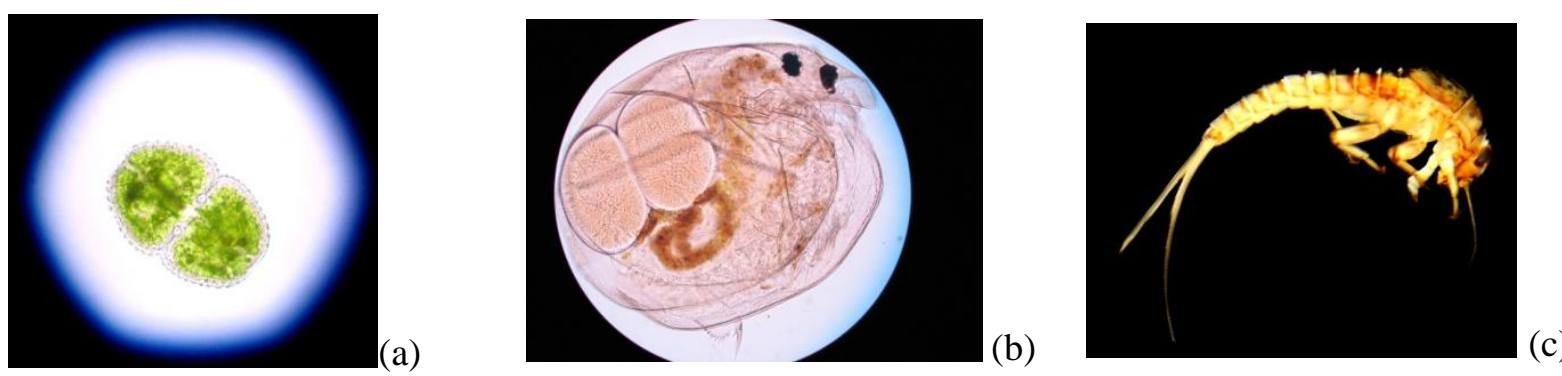

Figure 5. Groups of organisms from different trophic levels a) phytoplankton, b) zooplankton and c) macroinvertebrate.

\section{DISCUSSION}

Conservation of biodiversity ecosystems at landscape level is essential. Landscape ecology offers an effective framework to integrate patterns and processes, examine environmental dynamics and interactive pathways between landscapes; links research with management; and develops viable strategies for conservation. To be effective, conservation efforts should be based on a solid conceptual foundation and holistic understanding of natural ecosystems. The challenge for the future lies in protecting the ecological integrity and biodiversity of aquatic systems in the face of increasing pressures on freshwater resources (Ward, 1998). The presented research aims contributing to the basic understanding of aquatic ecosystems in high mountains by analyzing the natural variation of biota and quantifying the effect of natural environmental factors, in particular vegetative cover, hydrological connectivity and ultraviolet radiation.

The influence of native vegetation cover on aquatic communities is not extensively studied in the mountain region of South America. However, according to Sponseller et al. (2001) it has been proven that in the northern hemisphere landuse has a major effect on aquatic community composition. Streamside forest affect food quality and quantity for macroinvertebrates directly through inputs of particulate food (leaf, soil, wood) and indirectly by affecting the structure and productivity of microbial food web through shading and modifying the levels of dissolved organic carbon and nutrients (Sweeney, 1993). Forest canopy and its effect on incident levels of light that reach the stream is a major factor influencing benthic macroinvertebrate communities (Feminella et al., 1989). Streams with open canopy have been shown to have higher periphyton standing crops and primary production than more shaded areas (Fuller et al., 1986). As such macroinvertebrate grazers benefit from improved food resources when more sunlight reaches the channel and algal growth is stimulated. Shade influences water temperature and as such affect the species composition and life history characteristics of resident species (Sweeney, 1993). Taxon richness (including total number of Ephemeroptera, Plecoptera, and Trichoptera taxa) and Simpson's diversity of the macroinvertebrate community all heightens with increased tree cover at local scale in the Upper Thames River watershed in southwestern Ontario (Rios and Bailey, 2006). Colin et al. (2004) found significant differences between streams with pasture and tussock grass in percentage of macroinvertebrate based stream health index and macroinvertebrate density. They reported that macroinvertebrate biodiversity was generally higher in catchments with pasture than tussock land cover. Riley et al. (2003) consider this a reflection of the negative effects of sediment deposition being outweighed by a positive effect of higher nutrient levels on algal productivity fuelling more complex food webs (Townsend et al., 1998). Some studies deal with landuse changes such as the effect of deforestation on macroinvertebrate communities. Bucker et al. (in press) found in the high mountains of South Ecuador that on deforested areas macroinvertebrate density, species evenness and densities of certain taxa were different to 
forested areas. Odonata was completely lacking in deforested sites. Based on an extensive review of literature the authors expect to find very distinct macroinvertebrate communities in catchments with different vegetation cover. Measurement of all relevant environmental parameters followed by multivariate statistical processing of the data will reveal which variables are most important and significantly affect the aquatic communities.

There is a general neglect of small-scale landscape elements, such as freshwater ponds and pools yet, it has been shown in Europe that these small ecosystems contribute disproportionately to regional diversity (Oertli et al., 2002; Williams et al., 2004). In pond systems, one of the key environmental gradients structuring communities is the hydroperiod gradient (Brendonck and Williams, 2000). Further local environmental factors, both the abiotic environment and biotic interactions (competition, predation, parasitism and mutualism) may be important. Hydroperiod may induce a race against time and exerts a strong impact on species sorting and selection gradients (De Meester et al., 2005). In South America few research exist studying high mountain small lotic systems (i.e., Coronel et al., 2004; Coronel et al., 2007), however research on the effect of hydroperiod or the derived hydrological connectivity does not exist. Hydrological connectivity is defined by Pringle (2001) as the 'watermediated transfer of matter, energy, and/or organisms within or between elements of the hydrologic cycle'. Most studies deal with the importance of hydrological connectivity in rivers or streams, whereas hydrological connectivity at different land scales and directions is the most relevant for restoration measures (Jansson et al., 2007). It is to be expected that hydrological connectivity between small landscape elements (i.e., ponds) defined by natural hydroperiod (i.e., during wet season ponds have hydrological connectivity which might be disrupted during drier periods) also have an impact on the dynamics of aquatic communities. Florencio et al. (2008) found that macroinvertebrate community in Mediterranean temporary ponds changed in response to the hydroperiod. Studying ponds and pools and their natural variation during a hydrological period will provide a baseline to which any future change in the functioning of the system can be compared. Studying zooplankton in these systems might be the most appropriate since zooplankton is obligatory aquatic without terrestrial phases. Brendonck et al. (2000), for instance, showed significant patterns of isolation by distance in large branchiopods at individual rock-pool sites with clusters of close-set pools, and reported strong genetic differentiation, despite the fact that dispersal among pools by means of overflowing resting eggs can be abundant (Brendonck and Riddoch, 2000). Coronel et al. (2007) observed only very small differences in species numbers in temporary peat-pools in the Bolivian high mountains compared to neighboring lakes. Although these pools were small and with short hydroperiod, cladoceran species richness was in line with the larger and longer hydroperiod pools. In the Southern Ecuadorian high mountains rainfall does not represent high variation; there is no strong dry season and as such ponds do not dry out, however hydrological connectivity might shrink which probably explains endemism in the different ponds.

High mountain aquatic ecosystems are known to be exposed to high UV radiation. This can generate behavioral responses or morphological protection (i.e., production of protective pigments) in the aquatic organisms. To avoid UV damage, zooplankton applies different strategies including phenotypic changes, such as an increase in photo-protective pigments or an escape behavior, such as vertical migration (Hader et al., 2007). Furthermore, they can switch between strategies or select an optimally blended cocktail of available protection strategies. The evolutionary advantage of protective pigments is, likely, the ability to utilize the whole water column during daytime; conversely, since the amount of algal food is generally higher in surface waters; unpigmented individuals are restricted to a less preferred feeding habitat in deeper waters. Jansson et al. (2007) showed that Daphnia seems to rely on a combination of avoidance and pigmentation, whereas copepods almost exclusively rely on photo-protective compounds for their UV defense. Contrary, Speekmann et al. (2000) observed that pigmentation did not appear to play a role in UV radiation tolerance of 3 copepod species in estuarine environment. Alonso et al. (2004) sampled three interconnected lakes differing in their transparency and found that differences in the patterns of surface-water avoidance were unrelated to the abundance and vertical distribution of the dominant planktivores as well as to temperature and food availability. They were inversely related, however, to the average UV radiation levels within the surface layer. A UV avoidance strategy was strongly confirmed for the copepod Boeckella gracilipes, on account of its low UV tolerance and lack of photo-protective compounds. Exclusion experiments in a high altitude 
Andean lake indicated that the cladoceran Chydorus sphaericus and the rotifer Lepadella ovalis were strongly inhibited by UV-B (Cabrera et al., 1997). Conversely, UV-B radiation had no effect on the survival of the different life stages of the calanoid copepod Boeckella graalipes, suggesting a speciesspecific difference in the sensitivity to solar UV-B radiation. Moreover, no reduction in the number of copepod eggs per female and the number of nauplii produced was observed (Cabrera et al., 1997). Personal observation confirms the higher pigmentation in calanoid copepods and surface avoidance in the upper $3 \mathrm{~m}$ in the lagoon of Torreadora in Cajas National Park. The analyses of zooplankton samples will indicate the community structure at day and night at different depths of the lagoon and pigment analyses will show the pigmentation differences in the different species and individuals occupying various depths. All measured environmental variables (physical, chemical, and biological) will be used in multivariate statistics to explore which environmental variables in the studied areas are responsible for the structure in the zooplankton communities.

The ongoing research aims monitoring different high mountain aquatic ecosystems as to contribute to the baseline knowledge and assess the conservation status. The sampled ecosystems are situated in protected areas and as such they still can be considered as pristine with good conservation status. The impact of any future anthropogenic activities affecting these ecosystems can be quantified with reference to the baseline being the expected output of this research, on the basis of which appropriate conservation measures can be defined and put in place.

\section{ACKNOWLEDGEMENTS}

The authors would like to express their gratitude to SENACYT (Secretaria Nacional de Ciencia y Tecnología) for the financial support to carry out this research and to an anonymous reviewer for his helpful comments.

\section{REFERENCES}

Alonso, C., V. Rocco, P. Barriga, M.A. Battini, H. Zagarese, 2004. Surface avoidance by freshwater zooplankton: Field evidence on the role of ultraviolet radiation. Limnol. Oceanogr., 49(1), 225232.

Andrew, D.E., L.S. Clesceri, E.W. Rice, A.E. Greenberg, M.A.H. Franson, 2005. Standard Methods for the Examination of Water \& Wastewater: Centennial Edition. American Public Health Association, 21, $1134 \mathrm{pp}$.

Barros, S., M.C. Carrasco, 2006. Estudio limnologico en la laguna de Surocucho (Cuenca hidrografica de Llaviuco). Report ETAPA, 42 pp.

Brendonck, L., B.J. Riddoch, 2000. Dispersal in the desert rock pool anostracan Branchipodopsis wolfi (Crustacea: Branchiopoda). Crustacean Issues, 12, 109-118.

Brendonck, L., W.D. Williams, 2000. Biodiversity in wetlands of dry regions (drylands). In Biodiversity in Wetlands: Assessment, Function and Conservation, Vol. 1, Gopal, B, W.J. Junk, J.A. Davis (Eds). Backhuys Publishers: Leiden, The Netherlands, 181-194.

Brendonck, L., L. De Meester, B.J. Riddoch, 2000. Regional structuring of genetic variation in shortlived rock pool populations of Branchipodopsis wolfi (Crustacea: Anostraca). Oecologia, 123, 506-515.

Cabrera, S., M. Lopez, B. Tartarotti, 1997. Phytoplankton and zooplankton response to ultraviolet radiation in a high-altitude Andean lake: short- versus long-term effects. J. Plankton Res., 19(2), 1565-1582.

Calado, A.J., S.F.P. Almeida, S.C. Craveiro, 2005. Phycological surveys and monitoring in Portugal a summary. Algas - Boletine de la Sociedad Espanola de Ficologia, 36-41. 
Celleri, R., J. Feyen, 2009. The hydrology of tropical Andean ecosystems: Importance, Knowledge status and Perspectives. Mt. Res. Dev., 29(4), 350-355.

Colin, R.T., B.J. Downes, K. Peacock, C.J. Arbuckle, 2004. Scale and the detection of land-use effects on morphology, vegetation and macroinvertebrate communities of grassland streams. Freshwater Biol., 49, 448-462.

Coronel, J.S., S. Declerck, M. Maldonado, F. Ollevier, L. Brendonck, 2004. Temporary shallow pools in the high-Andes 'bofedal' peat lands: a limnological characterization at different spatial scales. Archives des Sciences, 57, 85-96.

Coronel, J.S., S. Declerck, L. Brendonck, 2007. High-altitude peatland temporary pools in Bolivia house a high cladoceran diversity. Wetlands, 27(4), 1166-1174.

de Bicudo, C.E., M. Menezes, 2006. Generos de algas de águas continentais do Brasil. RIMA, 498 pp.

De Meester, L., S. Declerck, R. Stoks, G. Louette, F. Van De Meutter, T. De Bie, E. Michels, L. Brendonck, 2005. Ponds and pools as model systems in conservation biology, ecology and evolutionary biology. Aquat. Conserv., 15, 715-725.

Dominguez, E., H.R. Ferandez, 2009. Macroinvertebrados bentonicos sudamericanos: sistematica y biologia. Fundación Miguel Lillo, Tucuman, Argentina, 656 pp.

Dudgeon, D., 2000. Going with the flow: large-scale hydrological changes and prospects for riverine biodiversity in tropical Asia. BioScience, 50, 793-806.

Feminella, J.W., M.E. Power, V.W. Resh, 1989. Periphyton responses to invertebrate grazing and riparian canopy in three northern California coastal streams. Freshwater Biol., 22, 445-457.

Florencio, M., L. Serrano, C. Gómez-Rodríguez, A. Millán, C. Díaz-Paniagua, 2008. Inter- and intraannual variations of macroinvertebrate assemblages are related to the hydroperiod in Mediterranean temporary ponds. Hydrobiologia, 634(1), 167-183.

Fuller, R.L., J.L. Roelofs, T.J. Fry, 1986. The importance of algae to stream invertebrates. J. N. Am. Benthol. Soc., 5, 290-296.

Häder, D.P., H.D. Kumar, R.C. Smith, R.C. Worrest, 2007. Effects of solar UV radiation on aquatic ecosystems and interactions with climate change. Photochem. Photobiol. Sci., 6, 267-285.

Jacobsen, D., A. Encalada, 1998. The macroinvertebrate fauna of Ecuadorian highland streams in wet and dry seasons. Arch. Hydrobiol., 142(1), 53-70.

Jacobsen, D., R. Schultz, A. Encalada, 1997. Structure and diversity of stream invertebrate assemblages: the influence of temperature with altitude and latitude. Freshwater Biol., 38, 247 261.

Jansson, R., C. Nilsson, B. Malmqvist, 2007. Restoring freshwater ecosystems in riverine landscapes: the roles of connectivity and recovery processes. Freshwater Biol., 52(4), 589-596.

Kundzewicz, Z.W., 2002. Ecohydrology-seeking consensus on interpretation of the notion. Hydrolog. Sci. J., 47(5), 799-804.

Mitsch, W.J., 1993. Ecological Engineering - a cooperative role with planetary life-support system. Environ. Sci. Technol., 27, 438-445.

Nelson, E., G. Mendoza, J. Regetz, S. Polasky, H. Tallis, D.R. Cameron, K.M.A. Chan, G.C. Daily, J. Goldstein, P.M. Kareiva, E. Lonsdorf, R. Naidoo, T.H. Ricketts, M.R. Shaw, 2009. Modeling multiple ecosystem services, biodiversity conservation, commodity production, and tradeoffs at landscape scales. Front. Ecol. Environ., 7(1), 4-11.

Oertli, B., J.D. Auderset, E. Castella, R. Juge, D. Cambin, J.B. Lachavanne, 2002. Does size matter? The relationship between pond area and biodiversity. Biol. Conserv., 104, 59-70.

Petts, G.E., Y. Morales-Chaves, J.P. Sadler, 2006. Linking hydrology and biology to assess the water needs of river ecosystems. Hydrol. Process., 20, 2247-2251.

Polis, G.A., D.R. Strong, 1996. Food web complexity and community dynamics. Am. Nat., 147(5), 813-846.

Pringle, C.M., 2001. Hydrological connectivity and the management of biological reserves: a global perspective. Ecol. Appl., 11, 981-998. 
Pringle, C.M., 2001. Hydrological connectivity and the management of biological reserves: a global perspective. Ecol. Appl., 11, 981-998.

Ríos, S.L., R.C. Bailey, 2006. Relationship between riparian vegetation and stream benthic communities at three spatial scales. Hydrobiologia, 553, 153-160.

Riley, R.H., Townsend, C.R., Niyogi, D.K., Arbuckle, C.A., K.A. Peacock, 2003. Headwater stream response to grassland agricultural development in New Zealand. New Zealand Journal of Marine and Freshwater Research, 37, 389-403.

Sites, R.W., M.R. Willig, M.J. Linit, 2003. Macroecology of aquatic insects: A quantitative analysis of taxonomic richness and composition in the Andes mountains of Northern Ecuador. Biotropica, 35(2), 226-239.

Smirnov, N.N., 1996. Cladocera: the Chydoridae and Sayciinae (Chydoridae) of the world. Series: H. J. Dumont (ed.) Guides to the Identification of the Macroinvertebrates of the Continental Waters of the World. SPB Academic Publishing, Vol. 11, 197 pp.

Speekmann, C.L., S.M. Bollens, S.R. Avent, 2000. The effect of ultraviolet radiation on the vertical distribution and mortality of estuarine zooplankton. J. Plankton Res., 22(12), 2325-2350.

Sponseller, R.A., E.F. Benfield, H.M. Valett, 2001. Relationships between land use, spatial scale and stream macroinvertebrate communities. Freshwater Biol., 46, 1409-1424.

Sweeney, B.W., 1993. Effects of streamside vegetation on macroinvertebratecommunities of White Clay Creek in Eastern North America. P. Acad. Nat. Sci. Phila., 144, 291-340.

Townsend, C.R., Thompson, R.M., McIntosh, A.R., Kilroy, C., Edwards, E. M.R. Scarsbrook, 1998. Disturbance, resource supply and food-web architecture in streams. Ecology Letters, 1, 200-209.

Ward, J.V., 1998. Riverine landscapes: Biodiversity patterns, disturbance regimes and aquatic conservation. Biol. Conserv., 83(3), 269-278.

Williams, P., M. Whitfield, J. Biggs, S. Bray, G. Fox, P, Nicolet, D. Sear, 2004. Comparative biodiversity of rivers, streams, ditches and ponds in an agricultural landscape in Southern England. Biol. Conserv., 115, 329-341.

Zalewski, M., 2002. Ecohydrology - integrative science for sustainable water, environment and society. Ecohydrol. Hydroecol., 2(1-4), 3-10.

Zalewski, M., 2000. Ecohydrology. The scientific background to use ecosystem properties as management tools toward susyainability of water resources. Guest Editorial. Ecol. Eng., 16, 1-8. 